\title{
Pengaruh Media Sosial Instagram @Zapcoid Terhadap Brand Equity Zap Clinic
}

\author{
Syafira Putri Kinanti, Berlian Primadani Satria Putri \\ Prodi Ilmu Komunikasi, Fakultas Komunikasi dan Bisnis, Universitas Telkom \\ syafiraputrikinanti@gmail.com dan berlianprimadani@gmail.com
}

\begin{abstract}
Technological development has provided to our generation an easier life in terms of connecting to each other with the blurring boundaries of time and place. According to a survey conducted by wearesocial.com in 2016, 79.0 million out of 88.1 million Internet users in Indonesia are active social media users. Therefore, there has been an increasing number of companies making use of social media to market their products, including ZAP Clinic. Along with the use of social media by ZAP Clinic, the brand equity of the company has become stronger as signified by the company being selected as TOP Brand Award 2016 for the first time. This research aims at understanding to what extent Instagram, as a social media, influences the brand equity of ZAP Clinic, through the company's Instagram account @zapcoid. This research used quantitative method with explanatory research as its type of research. The data was collected through online questionnaires that were spread via direct messages to Instagram followers of @ zapcoid that had done any treament at ZAP Clinic. Sample used in this research amount a hundred. The sampling technique was purposive, while the analysis technique was simple linear regression with the use of Statistical Package for Social Sciences (SPSS). This research demosntrates that social media $(X)$ significantly influences the equity of a brand for 0.621 or $62.1 \%$, while the remnant $37.9 \%$ is the contribution of other variables that were not assessed.
\end{abstract}

Keywords: brand equity, instagram, social media,

\begin{abstract}
Abstrak
Perkembangan teknologi internet di kehidupan manusia mempermudah komunikasi tanpa batas jarak dan waktu. Menurut survei yang dilakukan oleh wearesocial.com pada tahun 2016 dari 88.1 juta pengguna internet di Indonesia 79.0 juta merupakan pengguna aktif media sosial. Oleh karena itu banyak perusahaan yang memanfaatkan media sosial sebagai alat komunikasi pemasarannya, salah satunya adalah ZAP Clinic. Seiring dengan peningkatan kualitas media sosial yang dilakukan, brand equity ZAP Clinic pun semakin kuat yang ditandai oleh terpilihnya ZAP Clinic dalam TOP Brand Award 2016 untuk pertama kalinya. Penelitian ini bertujuan untuk mengetahui seberapa besar pengaruh media sosial instagram @ zapcoid terhadap brand equity ZAP Clinic. Metode penelitian yang digunakan adalah metode kuantitatif dengan jenis penelitian explanatory research. Pengumpulan data dalam bentuk kuesioner yang disebar secara online melalui direct message kepada followers akun instagram @zapcoid dan pernah melakukan treatment di ZAP Clinic. Sampel yang digunakan pada penelitian ini berjumlah 100 responden. Teknik sampling yang digunakan adalah purposive sampling. Teknik analisis data menggunakan analisis regresi linear sederhana dan dengan menggunakan aplikasi Statistical Package for Social Sciences (SPSS). Berdasarkan hasil analisis data dapat diketahui bahwa media sosial (X) berpengaruh signifikan terhadap brand equity sebesar
\end{abstract}


Syafira Putri Kinanti, Berlian Primadani Satria Putri: Pengaruh Media Sosial Instagram @Zapcoid Terhadap Brand Equity Zap Clinic

0,621 atau $62,1 \%$, sedangkan sisanya sebesar $37,9 \%$ lainnya merupakan kontribusi variabel lain yang tidak diteliti.

Kata Kunci: brand equity, instagram, media sosial

\section{Pendahuluan}

Perkembangan teknologi internet di kehidupan manusia memudahkan manusia untuk dapat berkomunikasi tanpa batas jarak dan waktu. Menurut survei yang dilakukan oleh website wearesocial.com pada tahun 2016 dari total populasi penduduk Indonesia yang berjumlah 259.1 juta, 88.1 juta diantaranya merupakan pengguna aktif internet dan dari 88.1 juta pengguna internet di Indonesia 79.0 juta merupakan pengguna aktif media sosial. Hal tersebut banyak dimanfaatkan oleh perusahaan untuk menggunakan internet dan media sosial sebagai alat komunikasi pemasarannya.

ZAP merupakan salah satu perusahaan yang bergerak dibidang klinik kecantikan yang memanfaatkan media sosial sebagai alat komunikasi pemasarannya. Media sosial yang digunakan oleh ZAP adalah twitter, facebook dan instagram.

Tabel 1. Akun Media Sosial ZAP

\begin{tabular}{ccc}
\hline Media Sosial & Tahun Pembuatan & Jumlah Followers \\
\hline Twitter & 2009 & 10.700 \\
Facebook & 2010 & 14.600 \\
Instagram & 2013 & 213.000 \\
\hline
\end{tabular}

Dari tabel 1 dapat dilihat bahwa instagram merupakan media sosial yang paling akhir di buat oleh ZAP namun memiliki jumlah followers paling banyak. Menurut hasil pengamatan yang penulis lakukan, pada akun instagram@zapcoid terus membuat perubahan yang positif terhadap konten-konten yang diunggah pada media sosial dari tahun 2013 sampai 2016 ini.

Tahun 2016 ini ZAP meraih penghargaan TOP Brand Award 2016 untuk pertama kalinya selama hampir tujuh tahun merintis usaha di bidang klinik kecantikan khususnya pada hair removal. ZAP mengalahkan para pesaingnya dalam kategori hair removal dengan Top Brand Index 49,3\%. Dengan terpilihnya ZAP dalam TOP Brand Award ini membuktikan bahwa ZAP merupakan merek yang menjadi pilihan konsumen, dengan kata lain ZAP berhasil mengkomunikasikan nilai-nilai perusahaannya dan memiliki brand equity yang tinggi di mata konsumennya. Oleh karena itu dengan data yang telah diuraikan diatas maka penulis ingin meneliti pengaruh penggunaan akun instagram terhadap brand equity ZAP dengan judul "Pengaruh Media Sosial Instagram @zapcoid Terhadap Brand Equity ZAP Clinic". 
Berdasarkan latar belakang tersebut, dapat dirumuskan masalah penelitian sebagai berikut: "Seberapa besar pengaruh media sosial instagram @zapcoid terhadap brand equity ZAP Clinic?". Penelitian ini bertujuan untuk mengetahui seberapa besar pengaruh sosial media instagram @zapcoid terhadap brand equity ZAP Clinic.

Konsep Teori yang digunakan dalam penelitian ini adalah media sosial dan brand equity. Konsep teori pertama, media sosial merupakan sebuah kelompok aplikasi berbasis internet yang dibangun atas dasar ideologi dan teknologi Web 2.0 dan memungkinkan penciptaan dan pertukaran user-generated content (Kaplan dan Haenlein, 2010). Menurut Chris Heuer dalam Solis (2010) terdapat empat $\mathrm{C}$ dalam penggunaan media sosial, yaitu:

1. Context: "How we frame our stories.", adalah bagaimana cara membingkai sebuah pesan (informasi) dengan memperhatikan penggunaan bahasa maupun isi dari pesan yang akan disampaikan.

2. Communication: "The practice of sharing our sharing story as well as listening, responding, and growing.", adalah bagaimana berbagi pesan (informasi) seperti mendengar, merespon dan tumbuh dengan berbagai macam cara agar pengguna merasa nyaman dan pesan tersampaikan dengan baik.

3. Collaboration: "Working together to make things better and more efficient and effective.", adalah bagaimana kedua belah pihak bekerja sama untuk membuat segala hal menjadi lebih baik. Dengan kerja sama antara sebuah akun atau perusahaan dengan penggunanya di media sosial untuk membuat hal baik lebih efektif dan lebih efisien.

4. Connection: "The relationships we forge and maintain.", adalah bagaimana memelihara hubungan yang telah terbina. Bisa dengan melakukan sesuatu yang bersifat berkelanjutan sehingga pengguna merasa lebih dekat dengan perusahaan pengguna media sosial.

Konsep teori kedua, brand equity. Menurut David A.Aker dalam Tjiptono (2011) brand equity adalah sekumpulan aset dan kewajiban (liabilities) merek yang berkaitan dengan sebuah merek, nama dan simbolnya, yang berdampak pada pengurangan atau penambahan nilai yang diberikan oleh sebuah produk atau jasa kepada perusahaan maupun pelanggan.

Menurut David A. Aker dalam Tjiptono (2011:97) brand equity dapat terbentuk oleh kontribusi empat dimensi aset merek:

1. Brand awareness: Kesanggupan seorang calon pembeli untuk mengenali atau mengingat kembali suatu merek sebagai bagian dari suatu kategori produk tertentu.

2. Brand associations: Segala hal yang memiliki keterkaitan dengan ingatan/memori mengenai suatu merek tertentu baik secara rasional dan emosional.

3. Perceived quality: Penilaian dan evaluasi yang bersifat subjektif dari pelanggan mengenai kualitas dan keunggulan dari suatu produk atau jasa secara keseluruhan. 
Syafira Putri Kinanti, Berlian Primadani Satria Putri: Pengaruh Media Sosial Instagram @Zapcoid Terhadap Brand Equity Zap Clinic

4. Brand loyalty: Suatu ukuran yang menunjukan sejauh mana keterkaitan antara konsumen dengan suatu merek tertentu yang mempengaruhi kemungkinan konsumen akan beralih atau tidak ke merek produk atau jasa lainnya.

Berdasarkan penelitian terdahulu yang dilakukan oleh Lavina Tresna \& Jovita Christin Wijaya (2015) dalam The Impact of Social Media Towards Brand Equity: An Empirical Study of Mall X menghasilkan kesimpulan bahwa social media marketing instagram yang dipraktikan oleh Mall $\mathrm{X}$ berkorelasi kuat dengan brand equity. Ia menyimpulkan bahwa salah satu cara untuk membedakan diri adalah dengan meningkatkan strategi pemasaran, terutama dalam hal pemasaran media sosial, untuk membangun ekuitas merek yang kuat. Begitu pun dengan penelitian yang dilakukan oleh Hamed Karamian et al (2015) yang menghasilkan kesimpulan bahwa media sosial memberikan pengaruh positif dan signifikan terhadap brand equity dengan hasil perhitungan $75 \%$ brand awareness, $80 \%$ brand loyalty dan $75 \%$ perceived quality.

Hipotesis penelitian awal adalah $\mathrm{H}_{0}$ : media sosial instagram tidak berpengaruh signifikan terhadap brand equity ZAP Clinic. $\mathrm{H}_{a}$ : media sosial instagram berpengaruh signifikan terhadap brand equity ZAP Clinic.

\section{Metode Penelitian}

Penelitian ini termasuk dalam penelitian korelasional yang menghubungkan antara variabel $\mathrm{X}$ (variabel bebas) dan variabel $\mathrm{Y}$ (variabel terikat) yang digambarkan dalam bagan sebagai berikut:

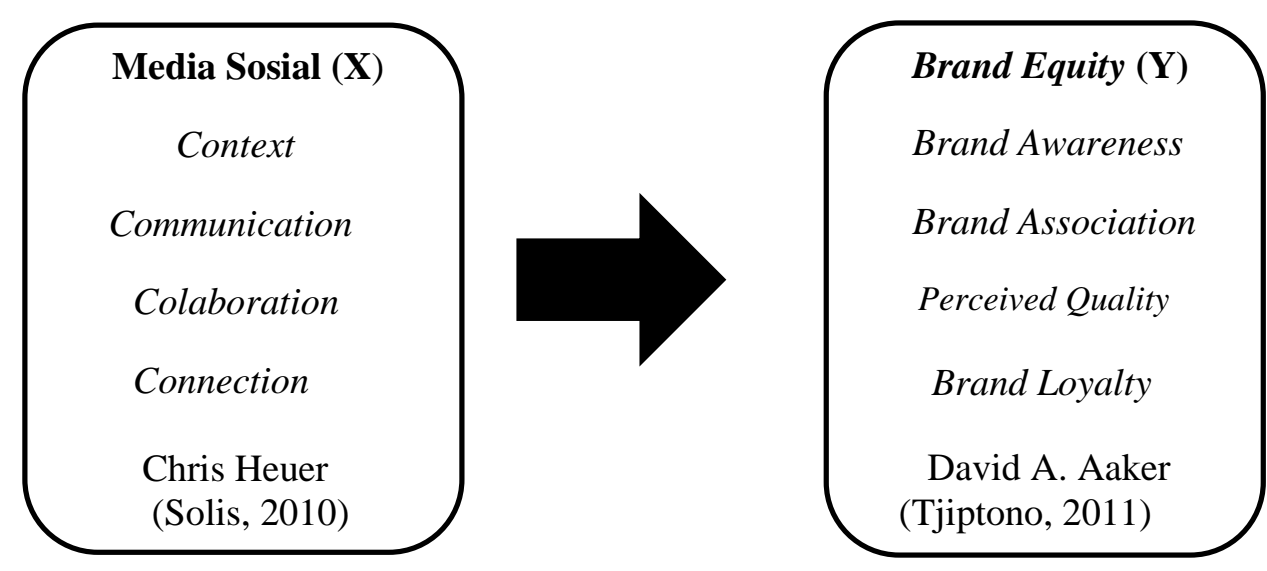

Gambar 1: Variabel X dan Y (Sumber: Olahan Peneliti)

Penelitian ini berlandaskan pada filsafat/paradigma positivisme yang memandang realitas/gejala/fenomena itu dapat diklasifikasikan, relatif tetap, kongrit, teramati, terukur, dan hubungan gejala bersifat sebab akibat (Sugiyono, 2014). Pendekatan yang digunakan adalah kuantitatif dengan jenis penelitian ekplanasi (explanatory research). Explanatory atau confirmatory research digunakan untuk menjelaskan hubungan kausal dan pengujian hipotesa 
(Singarimbun \& Effendi, 2006). Dalam penelitian ini peneliti ingin menguji pengaruh media sosial terhadap brand equity yang relevan dengan jenis penelitian yang dipilih.

Teknik pengumpulan data yang digunakan dalam penelitian ini adalah melalui kuesioner dan studi kepustakaan. Kuesioner dalam penelitian ini berisi daftar pertanyaan yang berhubungan erat dengan social media dan brand equity yang disebar kepada 100 responden dari followers instagram @ zapcoid melalui direct message instagram. Sedangkan pengumpulan data melalui studi kepustakaan dilakukan dengan mempelajari majalah, buku, literatur, jurnal, karya ilmiah atau penelitian terdahulu serta web browsing pada situs-situs yang relevan agar memperoleh informasi yang berhubungan dengan teori-teori atau konsepkonsep yang berkaitan dengan masalah dan variabel yang diteliti antara lain mengenai media sosial dan brand equity.

Variabel bebas dalam penelitian ini adalah media sosial. Variabel terikat dalam penelitian ini adalah brand equity. Berdasarkan tinjauan teori yang telah dipaparkan sebelumnya, terdapat indikator-indikator dari masing-masing variabel bebas dan terikat yang dapat di breakdown menjadi pertanyaan penelitian sebagai berikut:

Tabel 2. Operasionalisasi Variabel

\begin{tabular}{|c|c|c|c|c|}
\hline Variabel & Indikator & Ukuran & $\begin{array}{l}\text { No } \\
\text { Item }\end{array}$ & Skala \\
\hline \multirow[t]{7}{*}{$\begin{array}{l}\text { Media } \\
\text { Sosial } \\
(\mathbf{X})\end{array}$} & Context & $\begin{array}{l}\text { Pesan yang disampaikan di akun media } \\
\text { sosial instagram @ zapcoid dalam } \\
\text { menyediakan informasi tentang ZAP } \\
\text { Clinic jelas dan mudah dimengerti. }\end{array}$ & 1 & Likert \\
\hline & & $\begin{array}{l}\text { Tingkat kemenarikan media sosial } \\
\text { yang digunakan secara estetika. }\end{array}$ & 2 & Likert \\
\hline & Communication & $\begin{array}{l}\text { Informasi yang diberikan di akun } \\
\text { media sosial instagram @ zapcoid yang } \\
\text { menyediakan informasi tentang ZAP } \\
\text { Clinic lengkap dan up to date. }\end{array}$ & 3 & Likert \\
\hline & & $\begin{array}{l}\text { Respon admin di akun media sosial } \\
\text { instagram @ zapcoid dalam menjawab } \\
\text { pertanyaan anda tepat. }\end{array}$ & 4 & Likert \\
\hline & Colaboration & $\begin{array}{l}\text { Interaksi antara antara admin dengan } \\
\text { anda di akun media sosial instagram } \\
\text { @ zapcoid menyediakan informasi } \\
\text { tentang ZAP Clinic baik. }\end{array}$ & 5 & Likert \\
\hline & & $\begin{array}{l}\text { Tingkat keterlibatan dalam } \\
\text { memberikan like/comment/share di } \\
\text { akun media sosial instagram } \\
\text { @ zapcoid. }\end{array}$ & 6 & Likert \\
\hline & Connection & $\begin{array}{l}\text { Anda sering mencari kembali } \\
\text { informasi-informasi di akun media } \\
\text { sosial instagram @ zapcoid. }\end{array}$ & 7 & Likert \\
\hline
\end{tabular}


Syafira Putri Kinanti, Berlian Primadani Satria Putri: Pengaruh Media Sosial Instagram @Zapcoid Terhadap Brand Equity Zap Clinic

\begin{tabular}{|c|c|c|c|c|}
\hline Variabel & Indikator & Ukuran & $\begin{array}{l}\text { No } \\
\text { Item }\end{array}$ & Skala \\
\hline \multirow[t]{13}{*}{$\begin{array}{c}\text { Brand } \\
\text { Equity }(\mathbf{Y})\end{array}$} & $\begin{array}{l}\text { Brand } \\
\text { Awareness }\end{array}$ & $\begin{array}{c}\text { Anda mengetahui merek ZAP. } \\
\text { Anda dapat megenali merek ZAP } \\
\text { melalui logo/slogannya. }\end{array}$ & $\begin{array}{l}8 \\
9\end{array}$ & $\begin{array}{l}\text { Likert } \\
\text { Likert }\end{array}$ \\
\hline & & $\begin{array}{c}\text { Apabila Anda ingin melakukan } \\
\text { treatment hair removal, ZAP adalah } \\
\text { merek pertama yang terlintas dibenak } \\
\text { Anda. }\end{array}$ & 10 & Likert \\
\hline & $\begin{array}{l}\text { Brand } \\
\text { Associaton }\end{array}$ & $\begin{array}{c}\text { ZAP merupakan solusi untuk } \\
\text { perawatan kulit/menghilangkan bulu } \\
\text { Anda. }\end{array}$ & 11 & Likert \\
\hline & & $\begin{array}{c}\text { ZAP memiliki citra merek yang yang } \\
\text { lebih unggul } \\
\text { dibanding dengan merek } \\
\text { kompetitornya. }\end{array}$ & 12 & Likert \\
\hline & & $\begin{array}{l}\text { Anda mengetahui bahwa ZAP } \\
\text { merupakan pelopor hair removal } \\
\text { menggunakan teknologi penyinaran } \\
\text { (tanpa rasa sakit) pertama di Indonesia. }\end{array}$ & 13 & Likert \\
\hline & Perceived & $\begin{array}{l}\text { Anda tidak pernah mengalami masalah } \\
\text { setelah melakukan treatment di ZAP. }\end{array}$ & 14 & Likert \\
\hline & Quality & $\begin{array}{c}\text { ZAP memiliki kualitas pelayanan yang } \\
\text { baik dari dokter, terapis dan } \\
\text { receptionist. }\end{array}$ & 15 & Likert \\
\hline & & $\begin{array}{l}\text { ZAP memiliki variasi treatment dan } \\
\text { peralatan yang lengkap dan memadai. }\end{array}$ & 16 & Likert \\
\hline & & $\begin{array}{c}\text { Anda percaya pada kualitas merek } \\
\text { ZAP. }\end{array}$ & 17 & Likert \\
\hline & Brand Loyalty & $\begin{array}{c}\text { Anda terbiasa melakukan treatment di } \\
\text { ZAP. }\end{array}$ & 18 & Likert \\
\hline & & $\begin{array}{c}\text { Anda merasa puas jika melakukan } \\
\text { treatment ZAP. }\end{array}$ & 19 & Likert \\
\hline & & $\begin{array}{c}\text { Anda akan tetap melakukan treatment } \\
\text { di ZAP bahkan jika harganya } \\
\text { mengalami kenaikan. }\end{array}$ & 20 & Likert \\
\hline & & $\begin{array}{l}\text { Anda merekomendasikan ZAP sebagai } \\
\text { merek klinik kecantikan terbaik kepada } \\
\text { orang lain. }\end{array}$ & 21 & Likert \\
\hline
\end{tabular}

Skala yang digunakan dalam penelitian ini adalah skala likert. Skala likert digunakan untuk mengukur sikap, pendapat, dan persepsi seseorang atau sekelompok orang tentang fenomena sosial. Jawaban setiap item instrumen yang menggunakan skala Likert mempunyai gradasi dari sangat positif sampai sangat negatif, yang dapat berupa kata-kata (Sangat Seutuju, Setuju, Ragu-Ragu, Tidak Setuju, Sangat Tidak Setuju) dan diberi skor (1,2,3,4,5) (Sugiyono,2014). Menurut Sarjono (2011) skala Likert dengan empat pilihan jawaban dirasakan sebagai hal yang paling tepat. Dalam kenyataan dilapangan, sebagian besar 
responden akan memilih jawaban tengah "netral". Dengan demikian dalam penarikan kesimpulan, hasil penelitian yang diperoleh menjadi kurang akurat karena akan sulit memberikan kriteria penilaian pada jawaban netral. Oleh karena itu dalam penelitian ini menggunakan skala likert dengan empat pilihan jawaban yaitu Sangat Seutuju, Setuju, Tidak Setuju, Sangat Tidak Setuju.

Populasi yang digunakan adalah pengikut atau followers dari akun instagram @zapcoid yang pada tanggal 27 Oktober 216 mencapai 213.000 followers. Peneliti mengambil sampel sebesar 100 responden yang didapat dengan menggunakan rumus slovin rumus slovin (Prasetyo, 2012) :

$$
n=\frac{N}{1+N e^{2}}
$$

$n=$ Besaran sampel

$N=$ Besaran populasi

$e=$ Nilai kritis (batas ketelitian) yang diinginkan (persen kelonggaran ketidaktelitian karena kesalahpenarikan sampel) $(10 \%=0,1)$

$$
\begin{gathered}
n=\frac{213.000}{1+(213.000)(0,1)^{2}} \\
n=\frac{213.000}{1+(213.000)(0,01)} \\
n=\frac{213.000}{1+(213.000)(0,01)} \\
n=\frac{213.000}{1+2.130} \\
n=\frac{213.000}{2.131} \\
n=99,95=100
\end{gathered}
$$

Dalam penelitian ini, peneliti menggunakan teknik nonprobability sampling. Nonprobability sampling adalah teknik pengambilan sampel yang tidak memberi peluang yang sama bagi setiap unsur (anggota) populasi untuk dipilih menjadi anggota sampel. Jenis teknik nonprobability sampling yang digunakan adalah purposive sampling. Purposive sampling adalah teknik penentuan sampel dengan pertimbangan tertentu (Sugiyono, 2014). Teknik ini dipilih peneliti karena dianggap paling sesuai dengan penelitian yang akan dilakukan. Pengambilan sampel dilakukan kepada pengikut atau followers dari akun media sosial instagram @ zapcoid yang sudah pernah melakukan treatment di ZAP.

Teknik analisis data yang digunakan pada penelitian ini adalah analisis deskriptif, uji asumsi klasik meliputi uji normalitas dan heterokedastisitas, regresi linear sederhana, koefisien determinasi dan uji hipotesis (uji t). 
Syafira Putri Kinanti, Berlian Primadani Satria Putri: Pengaruh Media Sosial Instagram @Zapcoid Terhadap Brand Equity Zap Clinic

\section{Hasil Penemuan dan Diskusi}

\section{Karakteristik Responden}

Berdasarkan hasil kuesioner yang disebarkan kepada followers diakun instagram @zapcoid, penulis memperoleh data karakteristik responden yang terdiri dari usia, pekerjaan dan penghasilan sebagai berikut:

a. Usia: Sebagian besar responden yang diteliti sebanyak $44 \%$ berusia sekitar 18-24 tahun, frekuensi terbanyak kedua sebanyak $41 \%$ responden berusia sekitar $25-30$ tahun, sebanyak $12 \%$ responden berusia $>31$ tahun dan $3 \%$ responden lainnya berusia $<18$ tahun.

b. Pekerjaan: Sebagian responden sebanyak $35 \%$ berprofesi sebagai karyawan swasta, sebanyak $34 \%$ responden masih berstatus sebagai pelajar/mahasiswa, sebanyak $13 \%$ responden berprofesi sebagai wiraswasta dan $7 \%$ responden lainnya bekerja dibidang lain.

c. Penghasilan: Sebagian besar responden sebanyak $46 \%$ memiliki penghasilan sekitar 3-5 juta perbulan, frekuensi terbanyak kedua sebanyak $27 \%$ memiliki penghasilan sekitar 1-3 juta, sebanyak 15\% responden memiliki penghasilan sekitar 5-7 juta, sebanyak $11 \%$ responden memiliki penghasilan $>7$ juta perbulan dan $1 \%$ responden lainnya memiliki penghasilan $<1$ juta setiap bulannya.

\section{Analisis Deskriptif}

Perolehan skor untuk indikator media sosial sebesar $80,50 \%$ tersebut berada dalam kelas interval antara 62,50\% - 81,25\% dan berada dalam kategori baik. Dengan demikian dapat diambil kesimpulan bahwa penggunaan media sosial instagram@zapcoid berada dalam kategori baik dilihat dari keempat indikator yaitu context, communication, collaboration dan connection. Sedangkan perolehan skor untuk indikator brand equity sebesar $80,77 \%$ tersebut berada dalam kelas interval antara $62,50 \%-81,25 \%$ dan berada dalam kategori baik. Dengan demikian dapat diambil kesimpulan bahwa brand equity ZAP Clinic berada dalam kategori baik dilihat dari keempat indikator yaitu brand awareness, brand association, perceived quality, dan brand loyalty.

\section{Uji Normalitas}

Gambar dibawah ini menunjukan hasil pengujian normalitas data menggunakan metode grafik p-plot. Dari hasil perhitungan tersebut terlihat titik titik yang diperoleh masih mengikuti garis diagonal, sehingga dapat disimpulkan bahwa data yang digunakan memiliki sebaran data yang terdistribusi secara normal. Dengan demikian asumsi normalitas data terpenuhi. 


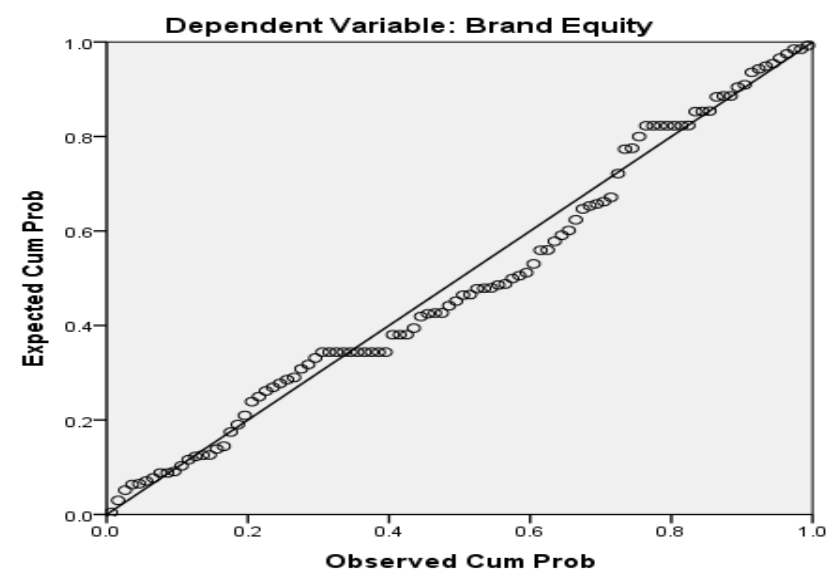

Gambar 2: Hasil Uji Normalitas Data (Sumber: Hasil Perhitungan SPSS)

\section{Uji Heteroskedastisitas}

Dari gambar 3 dibawah ini, diketahui bahwa titik-titik yang diperoleh membentuk pola acak tidak beraturan dan menyebar di atas dan dibawah angka nol (0) pada sumbu Y. Dengan demikian dapat diambil kesimpulan bahwa varians residual bersifat homokedastisitas.

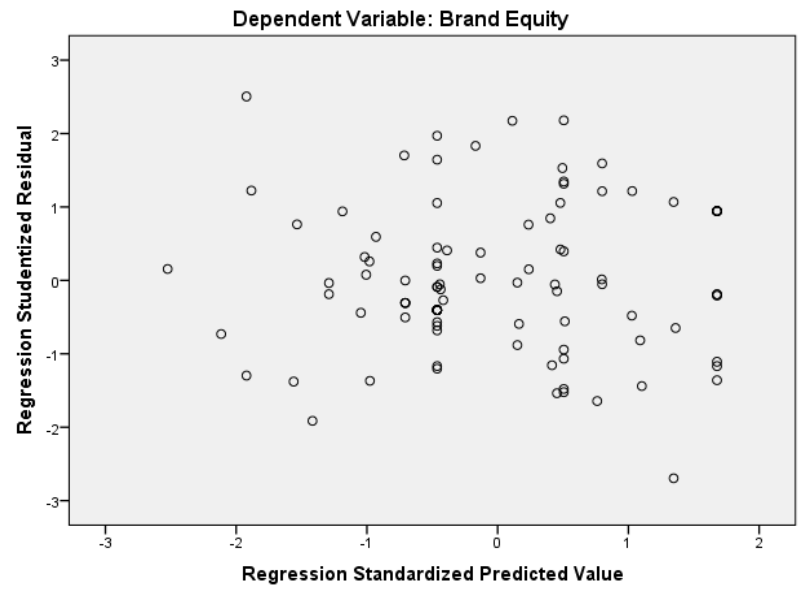

Gambar 3: Hasil Uji Heterokedastisitas (Sumber: Hasil Perhitungan SPSS)

Dari kedua pengujian asumsi normalitas dan heteroskedastisitas diatas, maka dapat disimpulkan bahwa tidak ditemukan adanya pelanggaran asumsi, sehingga analisis regresi linier sederhana bisa digunakan.

\section{Regresi Linier Sederhana}

Berdasarkan tabel output di atas, diperoleh nilai a sebesar 8,569 dan b sebesar 1,383. Dengan demikian, maka dapat dibentuk persamaan regresi linier sederhana sebagai berikut:

$$
\mathrm{Y}=8,569+1,383 \mathrm{X}
$$


Syafira Putri Kinanti, Berlian Primadani Satria Putri: Pengaruh Media Sosial Instagram @Zapcoid Terhadap Brand Equity Zap Clinic

Dari hasil persamaan regresi linier sederhana tersebut masing-masing variabel dapat diinterpretasikan sebagai berikut:

a. Konstanta sebesar 8,569 menunjukan bahwa ketika media sosial bernilai nol (0) dan tidak ada perubahan, maka brand equity ZAP clinic akan bernilai sebesar 8,569.

b. Variabel X yaitu media sosial memiliki nilai koefisien regresi sebesar 1,383 menunjukan bahwa ketika media sosial ditingkatkan, maka brand equity akan meningkat sebanyak 1,383 kali.

Tabel 3. Persamaan Regresi Linier Sederhana

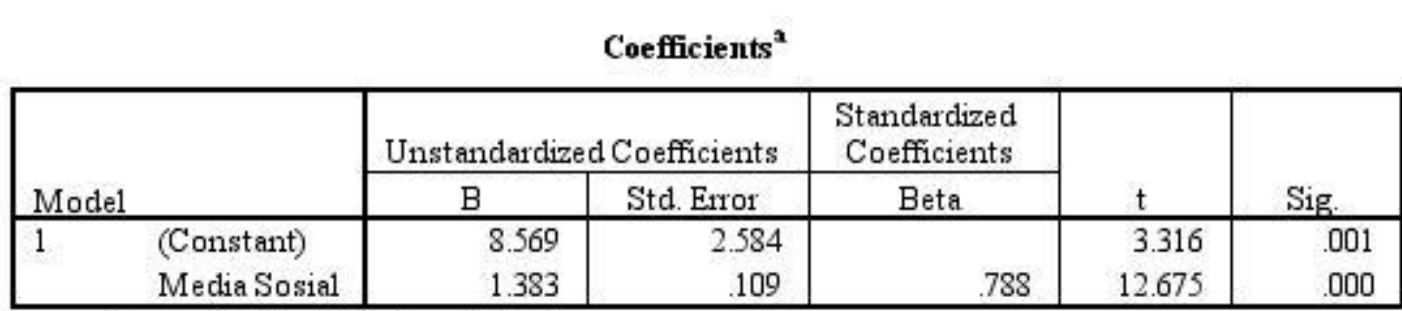

a. Dependent Variable: Brand Equity

\section{Koefisien Determinasi}

Tabel 4. Koefisien Determinasi

\begin{tabular}{|c|c|c|c|c|}
\hline \multicolumn{5}{|c|}{ Model Sumumary' } \\
\hline Model & $\mathrm{R}$ & RSquare & $\begin{array}{c}\text { Adjusted R } \\
\text { Square }\end{array}$ & $\begin{array}{l}\text { Std. Error of } \\
\text { the Estimate }\end{array}$ \\
\hline 1 & $.788^{2}$ & .621 & .617 & 5.18666 \\
\hline
\end{tabular}

Berdasarkan tabel 3, dapat dilihat bahwa Koefisien Korelasi (R) sebesar $0,788=78,80 \%$. Hal itu menunjukan bahwa variabel media sosial (X) memiliki hubungan yang kuat terhadap variabel brand equity $(\mathrm{Y})$. Dengan demikian koefisien determinasi dapat dihitung sebagai berikut:

$$
\begin{aligned}
\mathrm{KD} & =\mathrm{r}^{2} \times 100 \% \\
& =(0,788)^{2} \times 100 \% \\
& =62,1 \%
\end{aligned}
$$

Dari hasil perhitungan di atas terlihat bahwa nilai koefisien determinasi yang diperoleh sebesar $62,1 \%$. Hal ini menunjukan bahwa media sosial instagram @ zapcoid memberikan kontribusi terhadap brand equity ZAP clinic sebesar $62,1 \%$, sedangkan sisanya sebesar $37,9 \%$ lainnya merupakan kontribusi dari variabel lain yang tidak diteliti. 


\section{Uji Hipotesis (Uji t)}

Tabel 5. Pengujian Hipotesis

Coefficients $^{*}$

\begin{tabular}{|c|c|c|c|c|c|c|}
\hline \multirow[b]{2}{*}{ Model } & & \multicolumn{2}{|c|}{ Unstandardized Coefficients } & \multirow{2}{*}{$\begin{array}{c}\begin{array}{r}\text { Standardized } \\
\text { Coefficients }\end{array} \\
\text { Beta }\end{array}$} & \multirow[b]{2}{*}{$\mathrm{t}$} & \multirow[b]{2}{*}{ Sig. } \\
\hline & & $\mathrm{B}$ & Std. Error & & & \\
\hline 1 & $\begin{array}{l}\text { (Constant) } \\
\text { Media Sosial }\end{array}$ & $\begin{array}{l}8.569 \\
1.383\end{array}$ & $\begin{array}{r}2.584 \\
.109\end{array}$ & .788 & $\begin{array}{r}3.316 \\
12.675\end{array}$ & $\begin{array}{l}.001 \\
.000\end{array}$ \\
\hline
\end{tabular}

a. Dependent Variable: Brand Equity

Dari tabel di atas, diketahui bahwa nilai t-hitung yang diperoleh sebesar 12,675. Nilai ini akan dibandingkan dengan nilai t-tabel pada table distribusi $t$. Dengan taraf signifikasi $(\alpha)=5 \%=0,05$, derajat kebebasan $(\mathrm{df})=\mathrm{n}$ (jumlah sampel penelitian $)-\mathrm{k}$ (jumlah variabel penelitian $)=100-2=98$, diperoleh nilai $\mathrm{t}$-tabel pada tabel distribusi $\mathrm{t} \pm 1,984$. Dari nilai-nilai di atas terlihat bahwa nilai thitung 12,675 > t-tabel 1,984. Sesuai dengan kriteria pengujian hipotesis, jika nilai t-hitung > t-tabel maka $\mathrm{H}_{0}$ ditolak dan $\mathrm{H}_{\mathrm{a}}$ terima. Hal itu menunjukan bahwa media sosial instagram berpengaruh signifikan terhadap brand equity ZAP Clinic.

\section{Simpulan}

Berdasarkan hasil analisis data dan penelitian yang telah dilakukan pada followers akun media sosial instagram @ zapcoid yang juga pernah melakukan treatment di ZAP Clinic mengenai media sosial terhadap brand equity, maka penulis mengambil kesimpulan bahwa media sosial instagram @zapcoid berpengaruh signifikan terhadap brand equity ZAP Clinic dengan kontribusi sebesar $62,1 \%$, sedangkan sisanya sebesar $37,9 \%$ lainnya merupakan kontribusi dari variabel lain yang tidak diteliti dalam penelitian ini. Dari hasil analisis deskriptif dapat diketahui bahwa urutan indikator dari media sosial dari yang memiliki presentase paling tinggi adalah context (84\%), connection $(80,50 \%)$, communication $(80,25 \%)$ dan yang memiliki presentase paling rendah adalah colaboration $(77,25 \%)$. Sedangkan untuk urutan indikator brand equity dari yang memiliki presentase paling tinggi adalah brand awareness $(84,33 \%)$, perceived quality $(82,56 \%)$, brand association $(81,75)$ dan yang memiliki presentase paling rendah adalah brand loyalty $(75,56 \%)$.

\section{Ucapan Terimakasih}

Penulis mengucapkan terimakasih kepada pihak-pihak yang telah membantu dalam penelitian ini.

\section{Daftar Pustaka}

Kaplan, Andreas M., \& Haenlein, Michael. (2010). Users of the world, unite! The challenges and opportunities of social media. Business Horizons.

Karamian, Hamed, et all. (2015). Do Social Media Marketing Activities Increase Brand Equity?. TI Journals. 
Syafira Putri Kinanti, Berlian Primadani Satria Putri: Pengaruh Media Sosial Instagram @Zapcoid Terhadap Brand Equity Zap Clinic

Prasetyo, Bambang., \& Jannah, Lina Miftahul. (2012). Metode Penelitian Kuantitatif. Jakarta: RajaGrafindo Persada.

Sarjono, Haryadi., \& Julianita, Winda. (2011). SPSS vs LISREL: Sebuah Pengantar, Aplikasi untuk Riset. Jakarta: Salemba Empat.

Singarimbun, Masri., \& Effendi, Sofian. (2006). Metode Penelitian Survey. Jakarta: PT Pustaka LP3ES Indonesia.

Solis, Brian. (2010). Engage: The Complete Guide for Brands and Businesses to Build Cultivate and Measure Success on The Web. New Jersey: John Wiley \& Sons.

Sugiyono. (2014). Metode Penelitian Kuantitatif, Kualitatif, dan R\&D. Bandung: Alfabeta.

Tjiptono, Fandy. (2011). Manajemen \& Strategi Merek. Yogyakarta: ANDI.

Tresna, Lavina., et al. (2015). The Impact of Social Media Towards Brand Equity: An Empirical Study of Mall X. iBuss Management. 